\title{
Pre-analytical and Analytical Variables Affecting the Measurement of Plasma-Derived Microparticle Tissue Factor Activity
}

\author{
RD Lee ${ }^{1}$, DA Barcel ${ }^{2}$, JC Williams ${ }^{1}$, JG Wang ${ }^{1}$, JC Boles $^{1}$, DA Manly ${ }^{3}$, NS Key ${ }^{1}$, and N \\ Mackman ${ }^{1}$ \\ ${ }^{1}$ Division of Hematology/Oncology, Department of Medicine, University of North Carolina at \\ Chapel Hill \\ ${ }^{2}$ East Tennessee State University James H. Quillen College of Medicine, Johnson City, \\ Tennessee 37614, USA \\ ${ }^{3}$ Brody School of Medicine, East Carolina University
}

\section{Abstract}

\begin{abstract}
Introduction-Elevated levels of tissue factor positive $\left(\mathrm{TF}^{+}\right)$microparticles (MPs) are observed in plasma from a variety of patients with an increased risk of thrombosis. We and others have described the measurement of TF activity in MPs isolated from plasma. The aim of this study was to investigate the effects of pre-analytical and analytical variables on TF activity of MPs isolated from blood of healthy volunteers treated ex vivo with or without bacterial lipopolysaccharide.
\end{abstract}

Materials and Methods-We evaluated the following parameters: use of different centrifugation speeds to isolate the MPs; comparison of TF activity of MPs isolated from platelet poor plasma versus platelet free plasma; effect of freeze/thaw on MP TF activity; and comparison of the MP TF activity assay with the measurement of TF protein by ELISA or flow cytometry.

Results-MPs prepared from platelet poor plasma by centrifugation at $20,000 \times \mathrm{g}$ or $100,000 \times \mathrm{g}$ for 15 minutes had similar levels of TF activity. However, significantly less TF activity was found in MPs isolated from platelet free plasma compared with platelet poor plasma. Interestingly, freeze/thawing of the plasma showed donor to donor variation in MP TF activity, with a moderate increase in some individuals.

Conclusion- $\mathrm{TF}^{+}$MPs can be quantitatively isolated from platelet poor or platelet free plasma by centrifugation at $20,000 \times \mathrm{g}$ for 15 minutes. Measurement of MP TF activity in plasma can be used to detect a prothrombotic state in patients with various diseases.

\section{Keywords}

Microparticle; tissue factor; functional assay

(C) 2011 Elsevier Ltd. All rights reserved

Correspondence: Nigel Mackman, PhD Division of Hematology/Oncology Department of Medicine University of North Carolina at Chapel Hill Chapel Hill, North Carolina Tel 9198433961 Fax 9199667639 nmackman@med.unc.edu.

Publisher's Disclaimer: This is a PDF file of an unedited manuscript that has been accepted for publication. As a service to our customers we are providing this early version of the manuscript. The manuscript will undergo copyediting, typesetting, and review of the resulting proof before it is published in its final citable form. Please note that during the production process errors may be discovered which could affect the content, and all legal disclaimers that apply to the journal pertain. 
Tissue factor (TF) is a transmembrane protein that is the primary initiator of the coagulation cascade. TF is constitutively expressed on perivascular cells and epithelial cells and activates the clotting cascade in the event of vascular injury [1-3]. Very low levels of TF are also present in blood [4]. Recently, TF expression was found in a subset of resting monocytes [5]. Importantly, TF expression is strongly induced on monocytes exposed to bacterial lipopolysaccharide (LPS) [6, 7].

The majority of the low levels of TF present in plasma of healthy individuals is in the form of microparticles (MPs) [8]. These are small vesicles of variable size $(0.1-1 \mu \mathrm{m})$ that are released from many different cell types upon apoptosis or cellular activation and possess cell surface markers that are characteristic of their parental cells [9]. An alternatively spliced version of TF is also present in blood and is soluble due to the absence of a transmembrane domain [10]. Exposure of anionic phospholipids, such as phosphatidylserine (PS), on the surface of cells and MPs is associated with an increase in TF activity [11]. Increased levels of circulating $\mathrm{TF}^{+}$MPs have been found in various disease states, including cancer [12-14], sickle cell disease [15], myocardial infarction [16], venous thromboembolism (VTE) [17], endotoxemia and sepsis $[18,19]$. However, at present there is no standard method for the measurement of TF activity in plasma [8, 20,21].

The aim of the current study was to evaluate pre-analytical and analytical variables that affect levels of MP TF activity. We used blood from healthy volunteers treated ex vivo with LPS to generate monocyte-derived $\mathrm{TF}^{+}$MPs. We also compared levels of MP TF activity with levels of TF protein measured using two commercial TF ELISAs and by flow cytometry. Finally, we performed dilution linearity experiments to assess the lower limit of detection of the MP TF activity assay.

\section{Materials and Methods}

\section{Materials}

Bacterial lipopolysaccharide (LPS) (E. coli serotype 0111:B4) and mouse IgG were purchased from Sigma Aldrich (St. Louis, MO, USA). An inhibitory mouse anti-human TF monoclonal antibody (HTF-1) was generously provided by Dr. Ronald Bach (VAMC, Minneapolis, MN, USA). Human recombinant relipidated TF (Innovin) was obtained from Dade Behring (Marburg, Germany). Human Factor VIIa and Factor X were obtained from Enzyme Research (South Bend, IN, USA). The Factor Xa chromogenic substrate Pefachrome (FXa 8595) was obtained from Centerchem, Inc (Norwalk, CT, USA). The IMUBIND ${ }^{\circ}$ TF ELISA and the fluorescein isothiocyanate (FITC) conjugated, murine monoclonal antibody against human TF (Product no. 4507CJ) were obtained from American Diagnostica (Stanford, CT, USA). The ZYMUTEST TF ELISA kit was kindly provided by HYPHEN BioMed (France). FITC conjugated mouse IgG isotype control and allophycocyanin (APC) conjugated annexin V were obtained from BD Pharmingen (San Diego, CA, USA).

\section{Blood collection and treatment}

The subjects for this study were 14 healthy volunteers between the ages of 18-45. All subjects were Caucasian, and male subjects represented $80 \%$ of the group. Not all donors were used for every experiment. Samples were collected and processed in accordance with the Office of Human Research Ethics at UNC-Chapel Hill, and informed consent was obtained from all participating subjects. Blood was collected by venipuncture into Vacutainer ${ }^{\circledR}$ tubes containing $0.129 \mathrm{M}$ sodium citrate using a 21 gauge needle (BectonDickinson, Plymouth, UK). The first $3 \mathrm{~mL}$ of blood was discarded to minimize contamination from traumatic tissue injury. Control plasma was obtained by centrifugation 
of whole blood at the time of blood draw. Plasma containing elevated levels of $\mathrm{TF}^{+} \mathrm{MPs}$ was generated by treating whole blood with LPS $(10 \mu \mathrm{g} / \mathrm{ml})$ for 5 hours at $37^{\circ} \mathrm{C}$ with gentle rocking. Plasma samples were aliquoted, snap frozen, and stored at $-80^{\circ} \mathrm{C}$ for $\leq 1$ month before use.

\section{Plasma preparation and isolation of MPs}

Platelet poor plasma $(\mathrm{PPP})$ was prepared from whole blood by centrifugation at $1,500 \times \mathrm{g}$ for 15 minutes at room temperature. Platelet free plasma (PFP) was prepared from PPP with an additional centrifugation at $13,000 \times \mathrm{g}$ for 2 minutes at $4^{\circ} \mathrm{C}$. Plasma samples were either analyzed fresh or snap frozen in liquid nitrogen and stored at $-80^{\circ} \mathrm{C}$. MPs were pelleted from either PPP or PFP by centrifugation at either $20,000 \times \mathrm{g}$ or $100,000 \times \mathrm{g}$ for 15 minutes at $4^{\circ} \mathrm{C} .1 \mathrm{~mL}$ samples were spun in a fixed-angle, 45 degree rotor with 20 positions of 11 $\mathrm{mm}$ diameter each. For samples that were spun at $100,000 \times \mathrm{g}$, an ultracentrifuge with a fixed-angle rotor at 45 degrees was used (Optima ${ }^{\mathrm{TM}}$ TLX Ultracentrifuge, Beckman Coulter, Brea, CA, USA).

\section{MP TF activity assay}

A two stage chromogenic assay for the measurement of MP TF activity has been described [14].

\section{MP TF assay sensitivity and intra-assay variation}

The TF concentration of Innovin was determined using the IMUBIND® TF ELISA. An overlay of Innovin standard curves from 14 independent experiments was created by plotting observed values against the predicted value for each point. A regression line was fitted to the curve using statistical software. Dilution linearity experiments with MPs were also performed to determine the lower limit of the MP TF activity assay. PPP from LPS treated blood of 3 donors was serially diluted by half to $1 / 128$ the concentration of the original sample before MPs were prepared and MP TF activity was measured. The observed values, calculated from the standard curve, and the expected values, based on the dilution factor, were plotted on a log-log scale against $1 /$ dilution factor. The coefficient of variation (CV) was determined by dividing the standard deviation by the mean for each sample group.

\section{Flow cytometry}

MPs were isolated as described above from PFP derived from LPS-treated $(10 \mu \mathrm{g} / \mathrm{mL}, 5$ hours) or untreated blood. In addition, we analyzed MPs from untreated and LPS-treated THP-1 culture supernatant. Samples were analyzed fresh. MPs were stained in APOP buffer $\left(137 \mathrm{mM} \mathrm{NaCl}, 5 \mathrm{mM} \mathrm{KCl}, 1 \mathrm{mM} \mathrm{MgCl} 2,0.1 \% \mathrm{BSA} \pm 2.5 \mathrm{mM} \mathrm{CaCl}_{2}\right.$ ) with an APC conjugated annexin $\mathrm{V}$ (BD Pharmingen) and a FITC conjugated mouse monoclonal antibody to human TF (American Diagnostica). Samples were analyzed on the Becton-Dickinson LSR II (Plymouth, UK) with Flo Jo software. To ensure that an equal volume of each sample was analyzed, flow runs were terminated at either 1000 fluorescent flow count beads (Beckman Coulter) or after a 30 second time interval. Graph is expressed as the average fold increase of $\mathrm{TF}^{+}$annexin $\mathrm{V}^{+}$double positive MP events of treated versus untreated samples, in which untreated samples are standardized to a value of 1 .

\section{Measurement of TF by ELISA}

Plasma levels of human TF protein were measured by IMUBIND® TF ELISA kit (American Diagnostica) and ZYMUTEST TF ELISA kit (HYPHEN BioMed) according to the manufacturer's instructions. 


\section{Statistics}

For comparisons between multiple groups, a two-way ANOVA with Bonferroni post-test analysis was performed using GraphPad Prism version 5.00 for Windows (GraphPad Software, San Diego California USA). Unless otherwise noted, data are expressed as mean \pm standard deviation and statistical significance is defined by $\mathrm{p}<0.05$.

\section{Results}

\section{Sensitivity and intra-assay variability of the MP TF activity assay}

The MP TF activity assay uses a standard curve generated with different concentrations of recombinant TF (Innovin, Dade Behring). We assessed the standard error and goodness of fit of 8 points along the curve from 14 standard curves performed on different days. Though error increased with higher concentrations of TF, we found that the standard error and standard deviation from the mean was minimal (SEM $\leq 0.02$, sd $\leq 0.08$, Figure $1 \mathrm{~A}$ ). In order to assess the sensitivity of the MP TF functional assay, we used PPP from LPS treated blood of 3 donors, serially diluted to $1 / 128$ of the original concentration. MPs were isolated and TF activity measured. As shown in Figure 1 B-D, the actual value obtained deviated from the value expected from the dilution factor at $0.52,0.34$, and $0.03 \mathrm{pg} / \mathrm{mL}$ for the 3 donors, indicating that the sensitivity of the assay was $\sim 0.50 \mathrm{pg} / \mathrm{mL}$.

To evaluate the between run, intra-operator variability of the MP TF activity assay we calculated the CV of LPS-stimulated samples from four independent studies, with 3-5 assays per study run on different days. The CV in each independent study ranged from 12$25 \%$.

\section{Comparison of the MP TF activity and protein assays}

We prepared plasma from unstimulated and LPS stimulated blood and measured levels of MP TF activity and TF protein in the plasma using two commercial sandwich ELISAs. In each assay, plasma from the same six donors was used. MPs were isolated by centrifugation at 20,000 $\times \mathrm{g}$ for 15 minutes. The mean level of MP TF activity for the unstimulated samples was below the lower limit of detection of the assay $(0.11 \pm 0.07 \mathrm{pg} / \mathrm{mL})$. All donors exhibited a large increase in MP TF activity in blood treated with LPS compared with unstimulated controls (Figure 2A). Consistent with the known variability in LPS response in the population, we observed differences in the level of TF induction among the individual donors [5]. Levels of MP TF activity in LPS treated blood from the different subjects ranged from $2.0-14.4 \mathrm{pg} / \mathrm{mL}$. In contrast to the MP TF activity assay, unstimulated plasma samples had a high signal in the IMUBIND® TF ELISA (Figure 2B). The level of TF was modestly increased by LPS treatment in plasma from 5 of 6 donors with the IMUBIND® TF ELISA (1.4 \pm 0.3 fold, Figure 2B) but was not increased using the ZYMUTEST TF ELISA (Figure 2C). Notably, there were large differences in basal levels of TF protein between the two ELISAs with a high level in the IMUBIND® ELISA $(263.9 \pm 32.9 \mathrm{pg} / \mathrm{mL})$ and a low level in the ZYMUTEST ELISA $(8.8 \pm 1.9 \mathrm{pg} / \mathrm{mL})$.

Next, the number of $\mathrm{TF}^{+} \mathrm{PS}^{+}$double positive MPs was analyzed by flow cytometry in a subset of the same cohort of volunteers $(n=5)$ and in THP- 1 culture supernatant as a positive control. Surprisingly, we found that numbers of $\mathrm{TF}^{+}$MPs isolated from PFP were not significantly increased compared with untreated samples. In contrast, significantly more $\mathrm{TF}^{+}$ $\mathrm{PS}^{+}$events were observed in the cell supernatant of LPS stimulated cells compared with the culture supernatant of untreated cells $(* * * p<0.001$, Figure 3$)$. 


\section{Pre-analytical variables affecting MP TF activity}

Different centrifugation speeds have been reported for the preparation of plasma and the isolation of MPs, with some studies using ultra high speed centrifugation, such as $100,000 \times$ $\mathrm{g}$, to pellet MPs [21]. We and others have used 20,000 $\times \mathrm{g}$ for 15 minutes to isolate MPs [14, 22]. Therefore, we compared the amount of MP TF activity isolated from PPP using 20,000 and $100,000 \times \mathrm{g}$. Pelleting MPs from PPP at these two centrifugal forces for 15 minutes yielded similar amounts of MP TF activity from LPS treated blood (Figure 4A). Next, we compared the amount of MP TF activity from either PPP or PFP derived from the same LPS treated blood using a 20,000 $\times \mathrm{g}, 15$ minute spin. Levels of MP TF activity from PFP were significantly lower (52\% reduction) than those isolated from PPP $(3.9 \pm 2.4$ vs. $2.2 \pm 1.9 \mathrm{pg} /$ $\mathrm{mL}$, Figure 4B).

\section{Effect of freeze/thaw on MP TF activity}

Cellular TF activity is significantly increased after cell lysis due to increased exposure of PS [11]. We hypothesized that freeze/thaw of plasma would increase PS levels on the surface of MPs and therefore increase TF activity. We compared TF activity of MPs isolated from fresh plasma versus plasma that was snap frozen and thawed once. Variable results were observed with the 5 donors, with PPP from 3 of 5 donors showing a modest increase in MP TF activity (1.3-2.3 fold) after a freeze-thaw cycle $(* \mathrm{p}<0.05, * * \mathrm{p}<0.01$, Figure $4 \mathrm{C})$. However, when the MP TF activities of the 5 donors were combined and the activity of the fresh sample defined as 1, the MP TF activity of frozen PPP compared to fresh failed to reach statistical significance (paired student's $t$-test, $\mathrm{p}=0.06$, data not shown).

\section{Discussion}

In this study, we determined the effect of pre-analytical plasma preparation and storage on MP TF activity. Currently, the lack of standardization of pre-analytical variables has hindered researchers analyzing MPs [8, 20, 21, 23]. The most critical and discrepant variables include methods of plasma preparation, MP isolation, and storage of samples. For example, assay variability has been shown to be associated with different centrifugation protocols [24, 25]. Ultra centrifugation of $\geq 100,000 \times \mathrm{g}$ for up to 60 minutes has been used to isolate MPs [15]. However, this may contaminate the MPs with smaller exosomes. We found no significant difference in TF activity of MP isolated from PPP using 100,000 $\times \mathrm{g}$ or $20,000 \times \mathrm{g}$ indicating that the lower speed is sufficient to quantitatively recover $\mathrm{TF}^{+} \mathrm{MPs}$ from plasma.

Previous studies have examined the number of MPs isolated from PFP and PPP using different centrifugation protocols. One study observed an $80 \%$ reduction in the number of MPs by spinning PPP at 13,000 $\times \mathrm{g}$ for 2 minutes [26]. Similarly, we found that MP TF activity from PFP was reduced by $52 \%$ compared to the MP TF activity obtained from PPP. Despite this reduction, the level of MP TF activity was still easily detected in PFP. Another study found that plasma prepared using $2,000 \times \mathrm{g}$ for 10 minutes followed by $21,472 \times \mathrm{g}$ for 10 minutes had 10 fold less MPs than PPP (prepared by $1,550 \times \mathrm{g}$ for 20 minutes) [27].

Since our assay measures the procoagulant activity of TF that is affected by the availability of PS, cryopreservation and storage of samples is a critical pre-analytical variable when analyzing samples for MP TF activity. For instance, freezing of PPP results in platelet fragmentation [28]. Another study found that the total number of MPs and $\mathrm{TF}^{+}$MPs was decreased by freeze-thaw [29]. There is also some discrepancy in the literature regarding PS exposure on MPs. One study found a 20 fold increase in surface PS on MPs after freezethawing by flow cytometry [26]. In contrast, another group did not observe a change in PS exposure after freeze-thawing of MPs by flow cytometry (F. Dignat-George, pers. com.). 
This is consistent with Tesselaar and colleagues [12] who found no difference in MP TF activity in fresh versus frozen and thawed samples. We found donor to donor variability in MP TF activity of fresh PPP and PPP that had been snap frozen and thawed once, with 3 of 5 donors exhibiting an increase in activity. It is possible that some of this variability may be due to differences in platelet contamination of the PPP. MP TF activity may be increased in samples with higher levels of platelets due to PS exposure on the platelets. However, it should be noted that the increase in TF activity in these 3 donors after freeze/thaw was modest (1.3-2.3 fold), and no significant increase in TF activity was observed when data for the 5 donors was combined. These results may explain some of the reported discrepancies in the effect of freeze/thaw on PS exposure on MPs and MP TF activity.

We compared our MP TF activity assay with two different methods that measure TF protein. We found the MP TF activity assay was able to detect much larger differences in LPS stimulated versus unstimulated samples with low background activity in the unstimulated samples. Only one of the two commercial TF ELISAs showed a modest increase in TF protein levels after LPS stimulation but had a high basal level of TF protein $(263.9 \pm 32.9$ $\mathrm{pg} / \mathrm{mL}$ ). One study raised concerns about the high levels of TF protein levels detected using commercial TF ELISAs [30]. In a previous study, we found a much lower level of TF protein $(27 \mathrm{pg} / \mathrm{ml})$ in healthy individuals using an "in-house" TF ELISA [14]. Using flow cytometry, we found no statistical difference between levels of $\mathrm{TF}^{+} \mathrm{MP}$ isolated from unstimulated and LPS stimulated blood. In contrast, MPs isolated from LPS-treated THP-1 culture supernatant showed a significant increase in TF protein compared with MPs derived from untreated THP- 1 culture supernatant $(* * * \mathrm{p}<0.001)$. One explanation for these results is that a large number of $\mathrm{TF}^{+}$MPs released from activated monocytes in whole blood bind to activated platelets and are removed by centrifugation and this significantly reduces their number in the plasma. We have found in a time-course experiment with LPS treated whole blood that levels of TF in monocytes precede the levels of TF in platelets [31], which is consistent with transfer of monocyte-derived $\mathrm{TF}^{+}$MPs to platelets. In addition, other studies have shown that monocyte-derived $\mathrm{TF}^{+}$MPs bind to platelets [32,33]. These results also suggest that the TF activity assay is more sensitive than flow cytometry in detecting $\mathrm{TF}^{+}$ MPs. However, $\mathrm{TF}^{+} \mathrm{MPs}$ can be detected in the plasma of patients with different diseases $[8,12,15,18,25]$, indicating that our in vitro model is not optimal for looking at $\mathrm{TF}^{+} \mathrm{MPs}$ by flow.

The dilution linearity experiments indicate that MP TF activity below $0.5 \mathrm{pg} / \mathrm{mL}$ cannot be accurately detected with this assay. Importantly, we have shown that plasma from cancer patients have higher MP TF activities than $0.5 \mathrm{pg} / \mathrm{mL}$, while plasma from healthy individuals tend to have levels below this concentration [14, 34]. We observed a CV of 12$25 \%$ using different samples and with 3 different operators. A previous study reported a CV of $<10 \%$ using a similar MP TF activity assay [27]. These variations are inherent in a biological assay.

Standardization of the measurement of $\mathrm{TF}^{+} \mathrm{MPs}$ in plasma is needed so that results from different labs can be compared. $\mathrm{TF}^{+} \mathrm{MPs}$ may be a useful biomarker for identifying patients at risk for thrombosis. Further refinement of this and other assays is necessary for analysis of levels of $\mathrm{TF}^{+} \mathrm{MP}$ in clinical samples.

\section{Acknowledgments}

This work was funded by grants from the National Institutes of Health to NM (R01-HL006350) and NM and NK (R01-HL095096). JCB was supported by a grant from the National Hemophilia Foundation. 


\section{Abbreviations}

$\begin{array}{ll}\text { (MP) } & \text { Microparticle } \\ \text { (TF) } & \text { tissue factor } \\ \text { (PPP) } & \text { platelet poor plasma } \\ \text { (PFP) } & \text { platelet free plasma } \\ \text { (PS) } & \text { phosphatidylserine } \\ \text { (LPS) } & \text { bacterial lipopolysaccharide }\end{array}$

\section{References}

1. Mackman N. Tissue-specific hemostasis in mice. Arterioscler Thromb Vasc Biol. 2005; 25:227381. [PubMed: 16123318]

2. Drake TA, Morrissey JH, Edgington TS. Selective cellular expression of tissue factor in human tissues. Am J Path. 1989; 134:1087-97. [PubMed: 2719077]

3. Fleck RA, Rao LVM, Rapaport SI, Varki N. Localization of human tissue factor antigen by immunostaining with monospecific, polyclonal anti-human tissue factor antibody. Thromb Res. 1990; 57:765-81.

4. Giesen P, Rauch U, Bohrmann B, Kling D, Roque M, Fallon J, Badimon JJ, Riederer M, Nemerson Y. Blood-borne tissue factor: another view of thrombosis. Proc Natl Acad of Sci USA. 1999; 96:2311-5. [PubMed: 10051638]

5. Egorina EM, Sovershaev MA, Bjorkoy G, Gruber FX, Olsen JO, Parhami-Seren B, Mann KG, Osterud B. Intracellular and surface distribution of monocyte tissue factor: application to intersubject variability. Arterioscler Thromb Vasc Biol. 2005; 25:1493-8. [PubMed: 15860742]

6. Gregory SA, Morrissey JH, Edgington TS. Regulation of tissue factor gene expression in the monocyte procoagulant response to endotoxin. Mol Cell Biol. 1989; 9:2752-5. [PubMed: 2503712]

7. Osterud B, Bjorklid E. Sources of tissue factor. Semin Thromb Hemost. 2006; 32:11-23. [PubMed: 16479458]

8. Key NS, Mackman N. Tissue factor and its measurement in whole blood, plasma, and microparticles. Semin Thromb Hemost. 36:865-75. [PubMed: 21049387]

9. Morel O, Toti F, Hugel B, Bakouboula B, Camoin-Jau L, Dignat-George F, Freyssinet JM. Procoagulant microparticles: disrupting the vascular homeostasis equation? Arterioscler Thromb Vasc Biol. 2006; 26:2594-604. [PubMed: 16990554]

10. Bogdanov VY, Balasubramanian V, Hathcock J, Vele O, Lieb M, Nemerson Y. Alternatively spliced human tissue factor: a circulating, soluble, thrombogenic protein. Nature Med. 2003; 9:458-62. [PubMed: 12652293]

11. Wolberg AS, Kon RH, Monroe DM, Ezban M, Roberts HR, Hoffman M. Deencryption of cellular tissue factor is independent of its cytoplasmic domain. Biochem Biophys Res Commun. 2000; 272:332-6. [PubMed: 10833414]

12. Tesselaar ME, Romijn FP, Van Der Linden IK, Prins FA, Bertina RM, Osanto S. Microparticleassociated tissue factor activity: a link between cancer and thrombosis? J Thromb Haemost. 2007; 5:520-7. [PubMed: 17166244]

13. Hron G, Kollars M, Weber H, Sagaster V, Quehenberger P, Eichinger S, Kyrle PA, Weltermann A. Tissue factor-positive microparticles: cellular origin and association with coagulation activation in patients with colorectal cancer. Thromb Haemost. 2007; 97:119-23. [PubMed: 17200778]

14. Khorana AA, Francis CW, Menzies KE, Wang JG, Hyrien O, Hathcock J, Mackman N, Taubman MB. Plasma tissue factor may be predictive of venous thromboembolism in pancreatic cancer. $\mathrm{J}$ Thromb Haemost. 2008; 6:1983-5. [PubMed: 18795992]

15. Shet AS, Aras O, Gupta K, Hass MJ, Rausch DJ, Saba N, Koopmeiners L, Key NS, Hebbel RP. Sickle blood contains tissue factor-positive microparticles derived from endothelial cells and monocytes. Blood. 2003; 102:2678-83. [PubMed: 12805058] 
16. Huisse MG, Lanoy E, Tcheche D, Feldman LJ, Bezeaud A, Angles-Cano E, Mary-Krause M, de Prost D, Guillin MC, Steg PG. Prothrombotic markers and early spontaneous recanalization in STsegment elevation myocardial infarction. Thromb Haemost. 2007; 98:420-6. [PubMed: 17721626]

17. Tesselaar ME, Romijn FP, van der Linden IK, Bertina RM, Osanto S. Microparticle-associated tissue factor activity in cancer patients with and without thrombosis. J Thromb Haemost. 2009; 7:1421-3. [PubMed: 19500241]

18. Aras O, Shet A, Bach RR, Hvsjulien JL, Slungaard A, Hebbel RP, Escolar G, Jilma B, Key NS. Induction of microparticle- and cell-associated intravascular tissue factor in human endotoxemia. Blood. 103:4545-53. [PubMed: 14988149]

19. Nieuwland R, Berckmans RJ, McGregor S, Boing AN, Romijn FP, Westendorp RG, Hack CE, Sturk A. Cellular origin and procoagulant properties of microparticles in meningococcal sepsis. Blood. 2000; 95:930-5. [PubMed: 10648405]

20. Lacroix R, Robert S, Poncelet P, Dignat-George F. Overcoming limitations of microparticle measurement by flow cytometry. Semin Thromb Hemost. 2011; 36:807-18. [PubMed: 21049381]

21. Jy W, Horstman LL, Jimenez JJ, Ahn YS, Biro E, Nieuwland R, Sturk A, Dignat-George F, Sabatier F, Camoin-Jau L, Sampol J, Hugel B, Zobairi F, Freyssinet JM, Nomura S, Shet AS, Key NS, Hebbel RP. Measuring circulating cell-derived microparticles. J Thromb Haemost. 2004; 2:1842-51. [PubMed: 15456497]

22. Leroyer AS, Isobe H, Leseche G, Castier Y, Wassef M, Mallat Z, Binder BR, Tedgui A, Boulanger CM. Cellular origins and thrombogenic activity of microparticles isolated from human atherosclerotic plaques. J Am Coll Cardiol. 2007; 20:772-7. [PubMed: 17306706]

23. Yuana Y, Bertina RM, Osanto S. Pre-analytical and analytical issues in the analysis of blood microparticles. Thromb Haemost. 105:396-408. [PubMed: 21174005]

24. Berckmans RJ, Neiuwland R, Boing AN, Romijn FP, Hack CE, Sturk A. Cell-derived microparticles circulate in healthy humans and support low grade thrombin generation. Thromb Haemost. 2001; 85:639-46. [PubMed: 11341498]

25. Biro E, Sturk-Maquelin KN, Vogel GM, Meuleman DG, Smit MJ, Hack CE, Sturk A, Nieuwland R. Human cell-derived microparticles promote thrombus formation in vivo in a tissue factordependent manner. J Thromb Haemost. 2003; 1:2561-8. [PubMed: 14738565]

26. Lechner D, Weltermann A. Circulating tissue factor-exposing microparticles. Thromb Res. 2008; 122(Suppl 1):S47-54. [PubMed: 18691500]

27. Auwerda JJ, Yuana Y, Osanto S, deMaat MP, Sonneveld P, Bertina RM. Microparticle-associated tissue factor activity and venous thrombosis in multiple myeloma. Thromb Haemost. 2011; 105:14-20. [PubMed: 21057704]

28. Mobarrez F, Antovic J, Egberg N, Hansson M, Jorneskog G, Hultenby K, Wallen H. A multicolor flow cytometric assay for measurement of platelet-derived microparticles. Thromb Res. 2010; 125:e110-6. [PubMed: 19939440]

29. Shah MD, Bergeron AL, Dong J-F, Lopez J. Flow cytometric measurement of microparticles: pitfalls and protocol modifications. Platelets. 2008; 19:365-372. [PubMed: 18791943]

30. Parhami-Seren B, Butenas S, Krudysz-Ambio J, Mann KG. Immunologic quantitation of tissue factor. J Thromb Haemost. 2006; 4:1747-55. [PubMed: 16879217]

31. Bach R, Jilma B, Mayr F, Johnson G, Long J, Hysjulien J, Key N. Time course of tissue factor procoagulant activity increases on mononuclear cells and platelets following endotoxin-induced systemic inflammation in humans. Blood. 2003; 102 Abs. \#2023.

32. Del Conde I, Shrimpton CN, Thiagarajan P, Lopez J. Tissue factor bearing microparticles arise from lipid rafts and fuse with activated platelets to initiate coagulation. Blood. 2005; 106:16041611. [PubMed: 15741221]

33. Rauch U, Bondermann B, Badimon JJ, Himber J, Riederer MA, Nemerson Y. Transfer of tissue factor from leukocytes to platelets is mediated by CD15 and tissue factor. Blood. 2000; 96:170175. [PubMed: 10891447]

34. Manly DA, Wang J-G, Glover S, Kasthuri R, Liebman HA, Key NS, Mackman N. Increased microparticle tissue factor activity in cancer patients with venous thromboembolism. Thromb Res. 2010; 125:511-512. [PubMed: 19854471] 

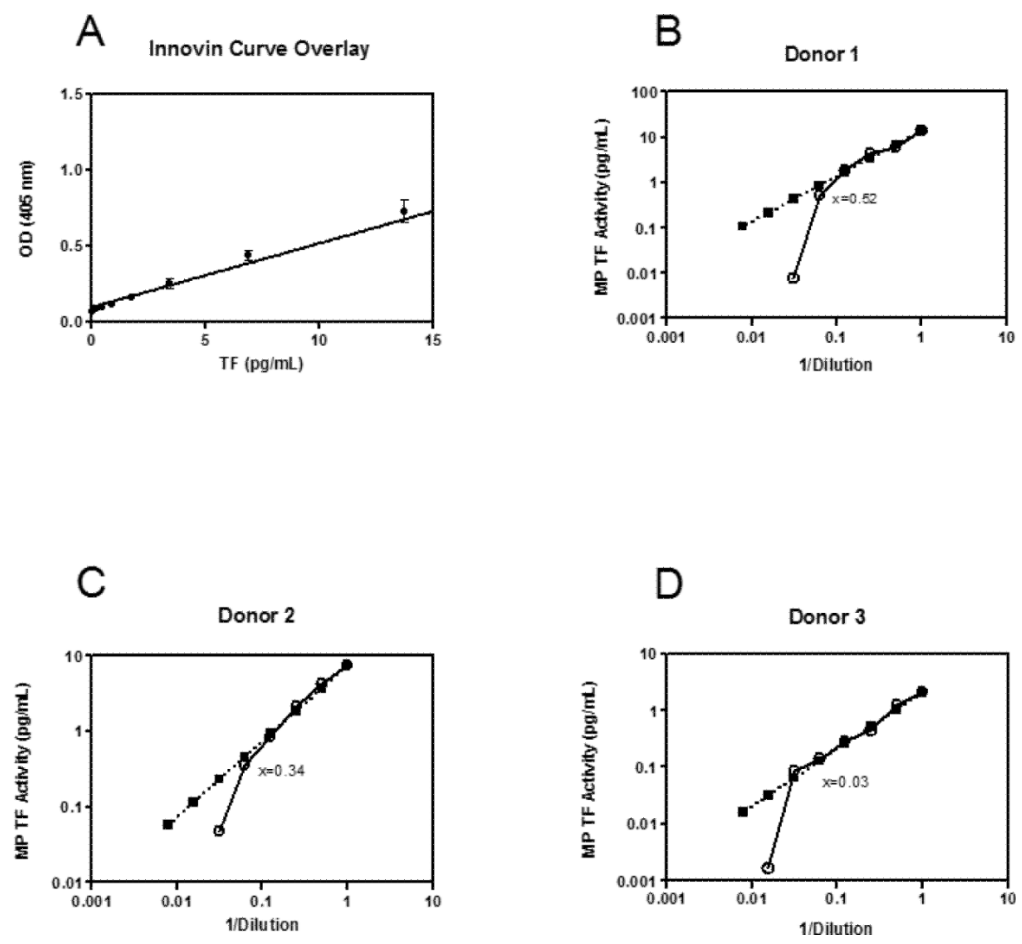

Figure 1. MP TF assay sensitivity

A) Standard curve of relipidated, recombinant MP TF from MP TF assays ( $n=14)$. OD values were back-calculated from the standard curve and plotted against the expected value for each point. A regression line was fitted to the curve using statistical software, $\mathrm{r}^{2}=0.97$. B-D) Dilution linearity plots from 3 donors, where $x$ equals the point at which the diluted sample deviates from the predicted curve. Black squares represent predicted values and white circles represent observed values. 
A

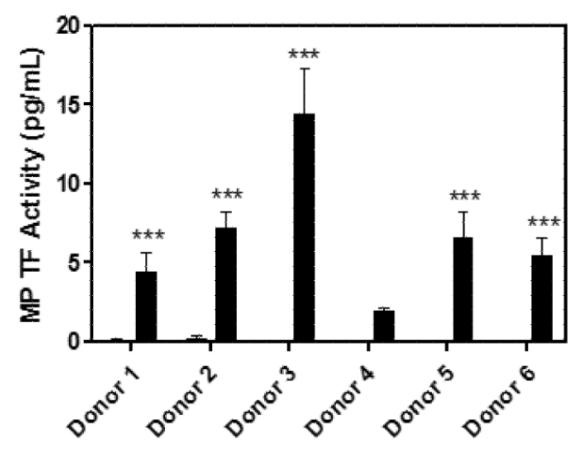

B

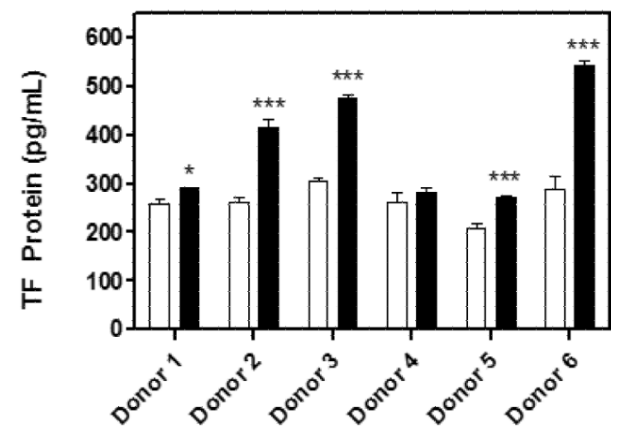

C

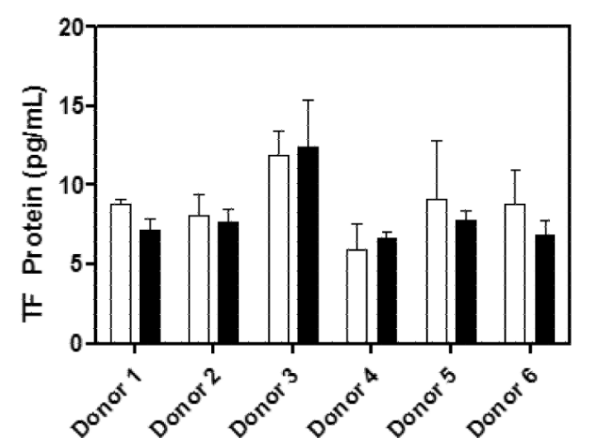

Figure 2. MP TF activity and protein in samples prepared from blood with and without LPS stimulation

Whole blood from 6 donors was either stimulated for 5 hours with LPS $(10 \mu \mathrm{g} / \mathrm{mL})$ or left untreated. PPP from blood with or without LPS stimulation was analyzed for A) MP TF activity and TF protein by B) IMUBIND® TF ELISA and C) ZYMUTEST TF ELISA. Black bars represent MP isolation from LPS treated blood and white bars indicate MPs isolated from untreated blood. Samples were run in triplicate, $* \mathrm{p}<0.05$, $* * * \mathrm{p}<0.001$, twoway ANOVA post-test. 


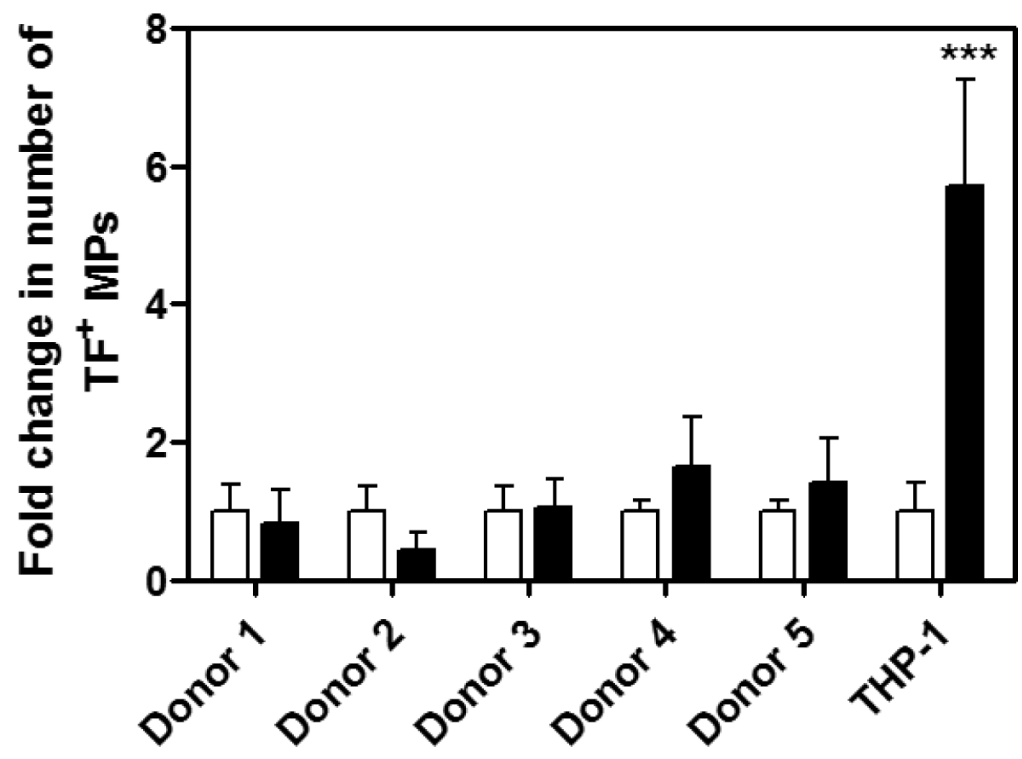

Figure 3. Flow cytometric analysis of $\mathrm{TF}^{+} \mathrm{PS}^{+} \mathrm{MPs}$

MPs were isolated by centrifugation of PFP from either untreated or LPS-stimulated whole blood from 5 donors or from centrifugation of untreated or LPS-stimulated THP-1 cell supernatant $(10 \mu \mathrm{g} / \mathrm{mL}$ of LPS, 5 hours). The graph is expressed as the average fold increase of $\mathrm{TF}^{+}$annexin $\mathrm{V}^{+}$double positive MP events of treated versus untreated samples, in which untreated samples are standardized to a value of 1. Black bars represent MP isolation from LPS treated blood or LPS treated THP-1 cells and white bars indicate MPs isolated from untreated blood or unstimulated cells. Samples were run in triplicate, $* * * \mathrm{p}<0.001$ by two way ANOVA post-test. 

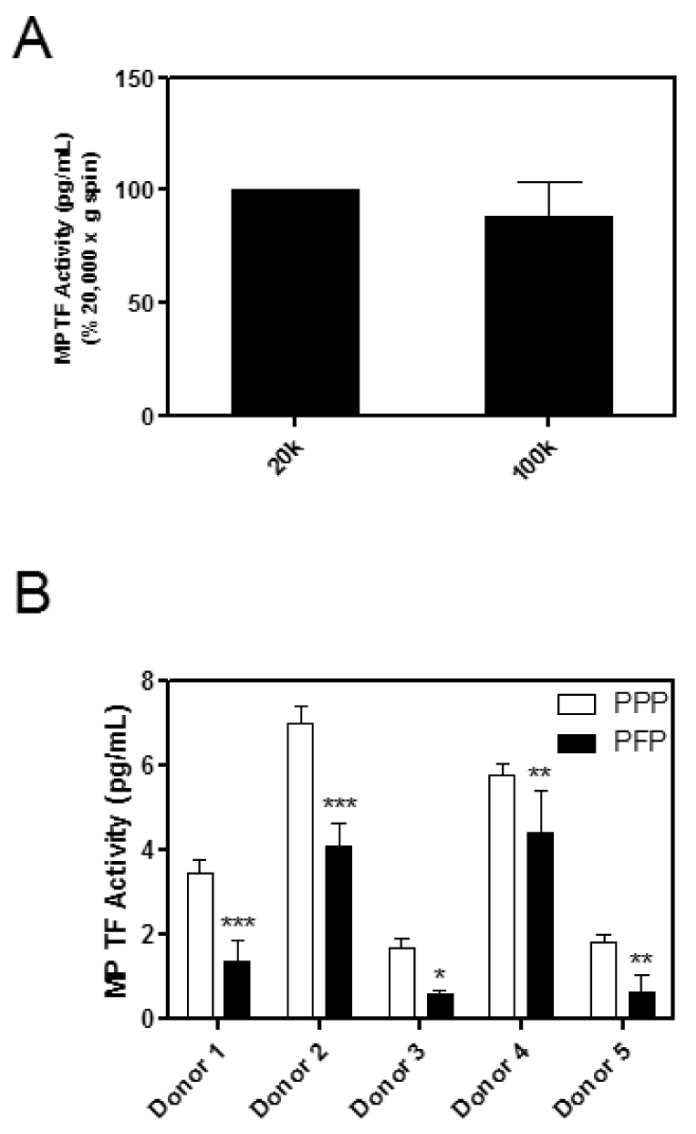

C

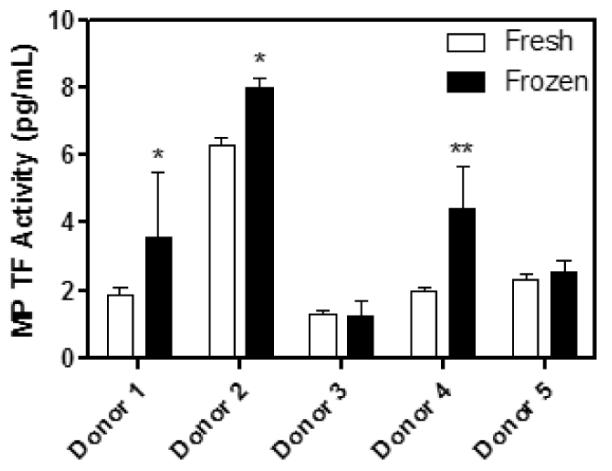

Figure 4. Effect of pre-analytical variables on MP TF activity

A) MP TF activity of PPP from whole blood from 6 donors stimulated with LPS $(10 \mu \mathrm{g} / \mathrm{mL})$ for 5 hours and then spun at either $20,000 \times \mathrm{g}$ or $100,000 \times \mathrm{g}$ for 15 minutes. B) MPs from 5 donors were isolated from PPP or PFP from LPS treated blood by centrifugation at 20,000 $\times$ $\mathrm{g}$ for 15 minutes. C) MP TF activity of PPP from LPS-stimulated blood was analyzed fresh or after being snap frozen and thawed once. Samples were run in triplicate, ${ }^{*} \mathrm{p}<0.05$, $* * \mathrm{p}<0.01, * * * \mathrm{p}<0.001$ by two way ANOVA post-test. 